\title{
MENINGKATKAN KUALITAS PEMBELAJARAN SEJARAH ASIA TIMUR MELALUI PENERAPAN METODE INKUIRI DI JURUSAN PENDIDIKAN SEJARAH FKIP UM MATARAM
}

\author{
Ahmad Afandi \\ Dosen Program Studi Pendidikan Sejarah FKIP, Universitas Muhammadiyah Mataram \\ Email : afandi190384@gmail.com
}

\begin{abstract}
ABSTRAK
Penelitian ini bertujuan untuk meningkatkan kualitas pembelajaran mata kuliah Sejarah Asia Timur di Program Studi Pendidikan Sejarah Fakuktas Keguruan dan Ilmu Pendidikan Universitas Muhammadiyah Mataram, melalui penerapan dan pengembangan model inkuiri. Pengembangan model ini dilatarbelakangi oleh perlunya dinamisasi dalam proses pembelajaran, sehingga dapat menghasilkan pembelajaran bermakna. Meningkatkan kualitas pembelajaran mahasiswa dalam pengertian mencari, menemukan, dan memecahkan permasalahan dalam perkuliahan dengan penerapan metode inkuiri, yang pada dasarnya juga merupakan penerapan metode sejarah kritis yakni: heuristik, kritik, interpretasi, dan historiografi. Metode yang digunakan dalam penelitian ini adalah penelitian kualitatif dengan strategi kaji tindak berbasis kelas atau penelitian tindakan kelas. Pemilihan metode ini berdasarkan asumsi bahwa perbaikan proses kegiatan pembelajaran di dalam kelas dapat dilaksanakan pengajar dengan melakukan refleksi tentang berbagai hal yang telah dilakukan dalam proses kegiatan pembelajaran, seperti penentuan tujuan pembelajaran, penyusunan materi ajar, sumber buku acuan yang digunakan, strategi pembelajarannya, alokasi waktu yang digunakan dan evaluasi. Aktivitas pengimplementasian tujuan penelitian ini dilakukan dengan pendekatan partisipatif kolaboratif antara pimpinan program, dosen, dan peneliti, sehingga terjadi sharing dalam penyusunan perencanaan tindakan. Hasil penelitian ini menunjukkan bahwa terjadi peningkatan kualitas pembelajaran pada mahasiswa semester III Program Studi Pendidikan Sejarah Fakuktas Keguruan dan IImu Pendidikan Universitas Muhammadiyah Mataram melalui pengembangan dan penerapan model inkuiri. Strategi inkuiri yang diterapkan diawali dengan strategi ekspositori yang menempatkan peranan besar dosen dalam pembelajaran terutama dalam hal membina, mengarahkan, membimbing, memberi tindakan, dan mengevaluasi serta refleksi, dan diakhiri dengan strategi inkuiri yang menuntut kemandirian mahasiswa dalam proses mencari, menemukan, dan memecahkan permasalahan yang berkaitan dengan masalah-masalah yang diajukan oleh dosen. Oleh karena itu, penelitian inikuiri ini tepat jika desebut sebagai model inkuiri terpimpin.
\end{abstract}

Kata Kunci: Inkuiri, Pembelajaran, Sejarah Asia Timur

\section{Pendahuluan}

Dalam rangka pengembangan pengajaran sejarah agar lebih fungsional dan terintegrasi dengan berbagai bidang keilmuan lainnya, maka terdapat berbagai bidang yang seyogianya mendapat perhatian, yaitu: pertama, untuk menjawab tantangan masa depan, kreativitas dan daya inovatif diperlukan agar bangsa Indonesia bukan sekedar manjadi konsumen IPTEK, konsumen budaya, maupun penerima nilai-nilai dari luar secara pasif, melainkan memiliki keunggulan komparatif dalam hal penguasaan IPTEK. Oleh karenanya, kreativitas perlu dikembangkan melalui penciptaan situasi proses belajar mengajar yang kondusif di mana pengajar mendorong vitalitas dan kreativitas peserta didik untuk mengembangkan diri. Peserta didik perlu diberi kesempatan untuk belajar dengan daya intelektualnya sendiri, melalui proses rangsangan-rangsangan baik yang berupa pertanyaan-pertanyaan maupun penugasan, sehingga peserta didik dapat melihat suatu hal dari berbagai sudut pandang dan dapat menemukan berbagai alternatif pemecahan masalah yang dihadapi. Kedua, peserta didik 
akan dapat mengembangkan daya kreativitasnya apabila proses belajar mengajar dilaksanakan secara terencana untuk meningkatkan dan membangkitkan upaya untuk kompetitif.

Oleh karena itu, proses belajar mengajar yang memberi peluang kepada peserta didik untuk menyelesaikan tugas secara kompetitif perlu disosialisasikan, kemudian juga perlu adanya penghargaan yang layak kepada mereka yang berprestasi. Hal ini akan berdampak positif terhadap terbentuknya rasa percaya diri pada peserta didik. Pada gilirannya, pengalaman ini selanjutnya dapat menjaga proses pembentukan kemandirian. Dalam hal ini peserta didik juga perlu dilibatkan dalam proses belajar mengajar yang memberikan pengalaman bagaimana peserta didik bekerja sama dengan peserta didik yang lain seperti dalam hal berdiskusi, membuat artikel kelompok, pengamatan, wawancara, dan sebagainya untuk dikerjakan secara kelompok. Pengalaman belajar seperti ini selanjutnya akan dapat membentuk sikap kooperatif dan ketahanan bersaing dengan pengalaman nyata untuk dapat menghargai segala kelebihan dan kelemahan masing-masing. Ketiga, dalam proses pengembangan kematangan intelektualnya, peserta didik perlu dipacu kemampuan berfikirnya secara logis dan sistematis.

Dalam proses belajar mengajar, pengajar harus memberi arahan yang jelas agar peserta didik dapat memecahkan suatu persoalan secara logis dan ilmiah. Oleh karena itu peserta didik perlu dilibatkan secara aktif dalam proses belajar mengajar melalui pemberian tugas. Tugas tidak terlalu berat tetapi dapat memacu daya berfikir peserta didik. Salah satu aspek yang penting adalah bagaimana peserta didik dapat terlatih berpikir secara deduktif-induktif. Artinya, dalam proses belajar mengajar peserta didik perlu diarahkan sedemikian rupa sehingga mereka dapat mempelajari materi pelajaran melalui pengalaman. Dengan cara seperti ini mereka dapat secara langsung dihadapkan pada suatu realita di lapangan. Seperti halnya peserta didik disediakan model pembelajaran yang bersifat khusus yang memberikan pengalaman, berdiskusi, penelitian, dan lain sebagainya yang diarahkan untuk menarik kesimpulan baik deduktif maupun induktif. Keempat, peserta didik harus diberi internalisasi dan keteladanan, dimana mereka dapat berperan aktif dalam kegiatan belajar mengajar. Fenomena ini dalam hal-hal tertentu dapat membentuk semangat loyalitas, toleransi, dan kemampuan adaptabilitas yang tinggi. Dalam hal pendekatan ini perlu diselaraskan dengan kegiatan proses belajar mengajar yang memberi peluang kepada mereka untuk berprakarsa secara dinamis dan kreatif.

Dengan demikian akan tercapai kualitas proses dan hasil belajar yang berorientasi pada pencapaian tujuan yang jelas, dengan melibatkan peserta didik secara maksimal melalui berbagai kegiatan yang konstruktif, sehingga pengalaman tersebut dapat mengantar mereka dalam suatu proses belajar yang kondusif dan kreatif. Dalam pembelajaran Sejarah Asia Timur, nilai mahasiswa juga belum menunjukkan hasil yang menggembirakan. Hal ini terlihat dari masih banyaknya mahasiswa yang mendapat nilai di bawah baik. Pada tahun ajaran 2013/2014 yang merupakan paket mata kuliah mahasiswa angkatan 2013, nilai mata kuliah Sejarah Asia Timur dari 47 peserta yang mendapatkan kategori A hanya 9 mahasiswa atau $19.9 \%$, kategori B ada 20 orang atau 42.5 $\%$, kategori C ada 16 orang atau 34.1, dan ada yang mendapat nilai D 2 orang atau $3.5 \%$. Begitu pula paket mata kuliah untuk mahasiswa angkatan tahun 2014, di mana jumlah peserta setelah ditambah dengan mahasiswa lama yang mengulang mata kuliah Sejarah Asia Timur Lama, mahasiswa yang mendapat nilai kategori A ada 9 orang atau $21.9 \%$, kategori B ada 19 orang atau $46.4 \%$, kategori $\mathrm{C}$ ada 13 orang atau $31.7 \%$. Sedangkan dalam mata kuliah Sejarah Asia Timur yang berlangsung pada semester genap, dimana jumlah mahasiswa yang mengambil mata kuliah ada 40 orang, mahasiswa yang mendapat nilai kategori $\mathrm{A}$ ada 11 orang atau $27.5 \%$, kategori B ada 18 orang atau $45 \%$, dan kategori $\mathrm{C}$ ada 11 orang atau $27.5 \%$. Dengan pengembangan sistem pembelajaran, diharapkan prosentase mahasiswa yang mendapat nilai kategori $\mathrm{A}$ akan 
lebih besar lagi. Untuk menjawab tantangan ini, maka dirasakan perlu untuk mengadakan penelitian tindakan kelas mengenai "Optimalisasi Penerapan Metode Inkuiri dalam Pembelajaran Mata Kuliah Sejarah Asia Timur di Program Studi Pendidikan Sejarah FKIP UM Mataram", sebagai bagian dari proses pendidikan.

\section{Metode Inkuiri dalam Kegiatan Pembelajaran \\ Edwin Fenton (1967: 262),} mengemukakan bahwa berdasarkan observasi terhadap strategi pembelajaran yang dilakukan oleh para pengajar sejarah, ternyata strategi itu bergerak pada suatu kontinum dari strategi ekspositori sampai pada strategi inkuiri. Strategi ekspositori menunjukkan keterlibatan unsur guru secara penuh menuntut keterlibatan mental guru untuk mampu memilih model dan metode mengajar yang sesuai dengan beban dan isi materi serta tujuan yang akan dicapai. Penentuan terhadap satu model mengajar akan membuka kemungkinan untuk menggunakan beberapa metode mengajar. Sedangkan strategi inkuiri menunjukkan keterlibatan siswa secara penuh dalam kegiatan belajar mengajar. Dalam kegiatan belajar mengajar, metode inkuiri merupakan suatu strategi pembelajaran yang memungkinkan para peserta didik untuk mendapatkan jawabannya sendiri (Soewarso, 2000: 57).

Metode inkuiri adalah metode pembelajaran yang dalam penyampaian bahan pelajarannya tidak dalam bentuknya yang final, tidak langsung. Artinya, dalam penyampaian metode inkuiri peserta didik sendirilah yang diberi peluang untuk mencari (menyelidiki/meneliti) dan memecahkan sendiri jawaban (permasalahan) dengan mempergunakan teknik pemecahan masalah. Sementara pengajar bertindak sebagai pengarah, mediator, dan fasilitator, yang wajib memberikan informasi yang relevan, sesuai dengan permasalahan atau materi pelajaran. Hal tersebut dapat berlangsung dalam kelompok-kelompok kecil dalam kelas melalui diskusi dan bermain peran. Dalam kegiatan ini peserta didik dituntut aktif terlibat dalam situasi belajar. Peserta didik menyadari masalah, mengajukan pertanyaan, selanjutnya menghimpun informasi sebelum mengambil keputusan (Munandar, 1995: 85). Proses inkuiri dapat dimulai dengan mengajukan permasalahan permasalahan yang kemudian harus dijawab dengan mencari dan mengumpulkan sumber-sumber yang relevan dengan permasalahan, baik berupa narasumber, buku-buku, majalah, jurnal, dan lain sebagainya.

Dengan metode ini berarti peserta didik terdorong untuk melakukan penyelidikan, yang berarti ada minat intrinsik untuk belajar mendapat pemahaman atau pengetahuan. Pembelajaran dengan metode inkuiri menempatkan peserta didik ke dalam situasi yang mana mereka harus ikut serta dalam operasi-operasi intelektual yang terdapat di dalamnya (Beyer, 1999: 6). Bertitik tolak dari konsep-konsep pembelajaran inkuiri serta dalam rangka untuk mendapatkan pemahaman yang optimal terhadap fakta-fakta atau peristiwa sejarah yang menjadi sumber materi sejarah, maka dalam penelitian tindakan ini penulis berupaya mengoptimalkan cara kerja metode inkuiri tersebut dalam pembelajaran di kelas.

Untuk penerapan metode inkuiri yang akan diupayakan pengoptimalannya dalam penelitian ini, adalah mengikuti model yang telah dikembangkan oleh Byron Massialas dan Benyamin Cox. Adapun tahap-tahap dalam strategi inkuiri model Massialas dan Cox adalah sebagai berikut.

1. Tahap pertama (orientasi) berisi kegiatan menetapkan masalah sebagai pokok bahasan yang akan dirumuskan dalam bentuk pertanyaan.

2. Tahap kedua (hipotesis), merumuskan hipotesis sebagai acuan inkuiri.

3. Tahap ketiga (definisi), menguraikan dan memperjelas hipotesis.

4. Tahap keempat (eksploratif), berupa menguji hipotesis menurut logika, yaitu yang disesuaikan dengan implikasi dan asumsi. 
5. Tahap kelima (pembuktian), mengumpulkan data dan fakta-fakta untuk membuktikan hipotesis.

6. Tahap keenam (generalisasi), yakni membuat kesimpulan sebagai pemecahan atau jawaban terhadap permasalahan yang dapat diterima kebenarannya.

III. Metode Penelitian

A. Tempat Penelitian

Penelitian tindakan kelas ini dilaksanakan di Program Studi Pendidikan Sejarah FKIP UMM pada mahasiswa semester III.

B. Bidang Penelitian

Bidang masalah yang akan dikaji adalah masalah pendidikan.

C. Sumber Data

Adapun jenis sumber data yang didapatkan dalam penelitian ini meliputi:

a. Data tentang perkembangan belajar, nama dan IPK mahasiswa

b. Data tentang kesiapan mahasiswa untuk melaksanakan proses pembelajaran dengan strategi inkuiri

c. Data tentang ketepatan waktu mahasiswa dalam melaksanakan tugas membuat makalah.

d. Data tentang kemampuan mahasiswa dalam mendapatkan sumber yang relevan dan tepat waktu

e. Data tentang situasi dan aktivitas pembelajaran di dalam kelas.

f. Data tentang partisipasi, keaktifan dan kreativitas mahasiswa

g. Data tentang penguasaan materi mahasiswa

h. Data tentang kemampuan mahasiswa dalam membuat keputusan dan menyimpulkan suatu masalah yang telah didiskusikan

i. Data tentang kemampuan pengorganisasian media pembelajaran j. Teks yang berupa arsip dan dokumen resmi mengenai program pengajaran, kurikulum, dan catatan-catatan lain yang relevan.

D. Pengumpulan Data

Pengumpulan data dilakukan melalui observasi, wawancara, dan mencatat dokumen seputar proses pembelajaran mata kuliah Sejarah Asia Timur.

E. Penerapan Siklus Penelitian

Pelaksanaan penelitian ini dilakukan dalam dua siklus, yakni siklus pertama sebagai implementasi tindakan, sedangkan siklus kedua sebagai perbaikan. Secara rinci tahapan kegiatan tersebut adalah sebagai berikut.

\section{Tahap I}

Perencanaan Tindakan Pada tahap ini meliputi kegiatan perencanaan tindakan yang dilakukan baik secara umum maupun secara khusus. Perencanaan umum dilaksanakan pada awal kegiatan penelitian yang meliputi penentuan tindakan umum, instrumen penelitian, dan pengukuran keberhasilan. Sedangkan perencanaan khusus dilakukan tiap siklusnya yang lebih menekankan pada implementasi tindakan per siklus. Rencana tersebut dilakukan dengan integrasi tindakan di dalamnya.

Tahap II

tindakan mempertimbangkan $\begin{array}{r}\text { Pelaksanan } \\ \text { beberapa }\end{array}$ pencapaian hasil yang diharapkan dalam proses pembelajaran. Dalam penerapan metode inkuiri sebagaimana dalam penelitian ini, proses pembelajaran ditafsirkan dalam pengertian luas. Pada tahap ini melibatkan peran aktif dan intensif secara bersama-sama antara dosen, peneliti, dan pakar pendidikan sejarah. Alur kegiatannya adalah siklus I sebagai berikut :

1. Kelas dibagi menjadi 6 kelompok, dan setiap dua kelompok dibimbing oleh seorang dosen yang dibantu oleh 1 orang asisten. Dosen memberikan informasi singkat tentang materi dan tugas yang harus dikerjakan oleh masing-masing 
kelompok dengan merumuskan masalahnya.

2. Masing-masing kelompok/individu diberikan waktu kurang lebih satu minggu untuk mencari sumber-sumber yang berkaitan dengan permasalahannya, dapat berupa narasumber, buku, majalah, jurnal, dan lain sebagainnya.

3. Setelah materi/sumber terkumpul dan sebelum permasalahan dipecahkan melalui diskusi, maka proses pengumpulan sumbersumber yang berkaitan dengan permasalahan, diberikan penilaian/skor yang berjenjang $1,2,3$, atau 4. Kriteria yang digunakan antara lain: ketepatan waktu dalam mengumpulkan sumber, kualitas sumber, jumlah sumber yang diperoleh, dan keaslian sumber.

4. Sewaktu diskusi dalam upaya membuktikan hipotesis yang dibuat, juga diberikan penilaian/skor: 1, 2, 3 atau 4, tergantung antara lain: keaktifan dalam berdiskusi, kualitas dalam memberikan jawaban atau sanggahan, dan lain sebagainya.

5. Sewaktu masing-masing membuat kesimpulan dari permasalahan yang dihadapi melalui diskusi, juga diberikan penilaian/skor 1, 2, 3, atau 4 tergantung dari kualitas hasil kerjanya masingmasing. Siklus dua juga menerapkan prosedur yang sama seperti pada siklus 1 , tetapi ketika memasuki siklus 2 diskusi kelompok dipersyaratkan memanfaatkan media dalam menyampaikan gagasan untuk lebih memperjelas penyampaian konsep-konsep dan gagasan dalam didksusi. Tahap III. Observasi dan Evaluasi Dalam tahap ini, observasi dilakukan oleh tim peneliti beserta asisten penelitian selama implementasi tindakan. Setelah itu kemudian dilakukan evaluasi hasil tindakan yang sudah dilakukan, melakukan verifikasi hipotesis tindakan, dan spesifikasi permasalahan yang belum teratasi. Pada tahap ini melibatkan seluruh tim peneliti termasuk pimpinan program studi.

\section{Tahap III}

Berdasarkan hasil observasi dan evaluasi, seluruh anggota tim peneliti melakukan refleksi. Dalam proses refleksi, setiap anggota tim peneliti dan semua partisipan bebas menyatakan pendapat berdasarkan hasil observasi dan evaluasinya. Refleksi dimaksudkan sebagai feed back untuk memikirkan kekurangan dan kelebihan dalam proses pembelajaran. Hasil refleksi digunakan sebagai acuan dalam perencanaan siklus yang selanjutnya. Siklus yang berikutnya merupakan perbaikan dari siklus sebelumnya dalam hal tindakan ataupun yang lain berdasarkan efek yang ditimbulkan atau hal lain yang terjadi pada siswa dalam proses pembelajaran.Tindakan dalam setiap siklus mengalami perubahan sesuai dengan kebutuhan dan hasil refleksi. Ketika siklus 1 selesai, maka hasil evaluasi dan refleksi merekomendasikan bahwa perlu penambahan penggunaan media oleh mahasiswa dalam memimpin diskusi.

\section{Hasil Penelitian}

Pembelajaran mata kuliah Sejarah Asia Timur, diberikan kepada mahasiswa Jurusan Pendidikan Sejarah, baik pada Program Studi IImu Sejarah, maupun Program Studi Pendidikan Sejarah. Bedanya, jika di Program Studi Pendidikan Sejarah mata kuliah tersebut diselenggarakan di semester IV, tetapi di Program Studi IImu Sejarah diselenggarakan pada semester III. Pada Program Studi Pendidikan Sejarah inilah penelitian tindakan kelas dilaksanakan dengan penerapan metode inkuiri untuk meningkatkan kualitas proses pembelajaran. Berdasarkan hasil observasi tim, lingkungan fisik kelas baik ruangan maupun lingkungan sekitar kurang mendukung. Ruang kuliah untuk kegiatan pembelajaran berada dekat jalan yang ramai dilalui kendaraan sehingga suasana bising.

Di samping itu, ruang kelas untuk pembelajaran mata kuliah Sejarah Asia Timur juga dilewati jalan-jalan strategis baik oleh dosen maupun mahasiswa, sehingga seringkali perkuliahan terganggu karena banyak orang yang lewat di depan ruang kelas. Sedangkan sarana dan prasarana kelas sudah cukup 
memadai, karena di setiap kelas sudah disediakan alat Bantu berupa OHP, dan jurusan juga memiliki LCD beserta perangkatnya yang dapat dipakai untuk kegiatan pembelajaran. Sedangkan masalah sumber belajar yang tersedia baik di jurusan maupun laboratorium masih sangat terbatas. Laboratorium sejarah tidak memiliki cukup sumber belajar untuk peningkatan kualitas pembelajaran. Oleh karena itu, ketika mahasiswa diminta untuk mencari sumber-sumber belajar, maka rata-rata mahasiswa merasa kesulitan untuk mendapatkannya, sehingga harus mencari di luar universitas, karena di universitas juga sumber-sumber yang berkaitan dengan mata kuliah Sejarah Asia Timur masih sangat terbatas. Begitu pula dengan media pembelajaran yang masih terbatas kuantitasnya, sehingga tidak setiap dosen dapat menggunakan alat dan media dalam waktu yang sama, karena digunakan oleh dosen lain. Begitu pula dengan kepemilikan sumber oleh mahasiswa masih sangat rendah jika tidak mau dikatakan miskin sumber.

Secara umum, proses pembelajaran berjalan dengan tertib, dan terjadi proses yang dialogis yang multi arah, sehingga pembelajaran terkesan impresif. Mahasiswa rata-rata ikut aktif dalam kegiatan pembelajaran, sehingga dapat dilihat bahwa mereka memiliki sikap yang positif dan serius terhadap mata kuliah. Terhadap diterapkannya metode inkuiri, mahasiswa juga menganggap baik terhadap strategi itu, terlebih diterapkan di Program Studi Pendidikan Sejarah yang rata-rata mahasiswanya kritis. Begitu pula dalam menanggapi tugas yang diberikan oleh dosen berkaitan dengan mata kuliahnya. Tanggapan mahasiswa terhadap strategi inkuiri adalah positif, tetapi menganggap bahwa faktor pendukung untuk diterapkannya metode tersebut masih sangat terbatas, sehingga proses pembelajaran kurang maksimal. Mahasiswa menilai bahwa rendahnya kualitas pembelajaran sejarah lebih banyak diakibatkan oleh minimnya sarana belajar. Contoh kasus yang kasat mata seperti eksistensi laboratorium yang lepas dari perhatian khalayak, menjadikan laboratorium semakin kehilangan fungsinya, karena mahasiswa lebih memilih untuk mencari sumber belajar di luar, sehingga laboratorium terkesan hanya sebagai museum belaka.

Melihat hal ini tentunya mahasiswa bertanya apakah begitu tidak berharganya Pendidikan Sejarah sehingga hampirhampir tidak diakui eksistensinya dalam masyarakat. Kondisi inilah yang menjadi penyebab utama ketertinggalan pembelajaran ilmu-ilmu sosial dibandingkan dengan ilmu-ilmu lainnya, termasuk pembelajaran sejarah. Melalui pengembangan metodologi dengan strategi inkuiri ini, diharapkan mahasiswa tidak lagi tergantung pada faktor pundukung yang bersifat teknis, tetapi lebih kepada substansinya dalam pembelajaran. Jumlah peserta mata kuliah Sejarah Asia Timur relative besar, yaitu sebanyak 46 mahasiswa yang terdiri dari mahasiswa semester III dan mahasiswa semester di atasnya yang mengulang atau memperbaiki. Dalam penerapan metode inkuiri, mahasiswa dibagi menjadi 6 kelompok di mana 4 kelompok pertama masing-masing 7 mahasiswa, sedangkan 2 kelompok berikutnya masing-masing 8 mahasiswa. Kelompok ini relatif besar karena strategi perkuliahan direncanakan dalam dua fase yaitu fase sampai ujian mid semester, dan fase sampai akhir semester. Penelitian action research dengan penerapan metode inkuiri, dilaksanakan pada fase pertama dengan dua siklus. Pada siklus pertama, kelompok diskusi yang maju presentasi sebanyak 3 kelompok, sedangkan 3 kelompok berikutnya pada siklus 2 . Sedangkan pada fase 2 yakni dari mid semester sampai akhir semester, adalah fase pasca penelitian yang juga tetap menggunakan metode inkuiri dengan berbagai perbaikan-perbaikan setiap siklusnya.

Dalam realisasi penerapan strategi inkuiri, semua kelompok tepat waktu dalam mengumpulkan sumber. Hal ini terbukti dengan terkumpulnya semua makalah diskusi tepat waktu, setelah selama 2 minggu mahasiswa diberi kesempatan untuk mencari sumber, mempelajarinya, dan menyusunnya dalam sebuah makalah diskusi. Namun demikian, dalam hal kualitas dan relevansi sumber, jumlah dan ragam sumber yang diperoleh, serta keaslian sumber rata-rata tiap kelompok 
mendapat skor 3 atau kategori baik. Data kualitatif ini menunjukkan bahwa ada keseriusan mahasiswa dalam melaksanakan strategi inkuiri yang lebih berpusat pada mahasiswa. Pada siklus 1, dalam diskusi kelompok setiap mahasiswa sudah cukup aktif dimana rata-rata kelompok mendapat skor 3 atau kategori baik. Kemampuan kerja tim, kualitas dalam memberi jawaban, kemampuan menghargai pendapat orang lain, kualitas dalam mengatur jalannya diskusi, juga sudah sudah baik rata-rata mendapat skor 3. Begitu pula dengan kualitas makalah diskusi yang sudah layak memenuhi tata tulis ilmiah. Dalam hal kemampuan menjadi pengamat diskusi, masing-masing kelompok sudah menunjukkan kerja yang baik, terlihat dari kemampuan masing-masing kelompok dalam mengambil kesimpulan baik lisan maupun tertulis. Demikian juga halnya kemampuan dalam memberikan umpan balik, masing-masing kelompok mendapat skor 3, atau rata-rata mampu memberikan umpan balik pada peserta diskusi. Dalam siklus 2, berdasarkan hasil pengamatan dan observasi selama pelaksanaan tindakan siklus 1, dipersyaratkan kepada kelompok untuk menggunakan media dalam menjelaskan konsep dalam diskusi. Hasilnya, terjadi peningkatan yang signifikan kualitas proses pembelajaran dibandingkan dengan siklus 1.

Proses pembelajaran menjadi lebih impresif, dan bahkan terjadi pembelajaran yang dialogis dan multi arah. Namun demikian, berdasarkan interpretasi tim peneliti dapat dikatakan bahwa kelompok yang paling menonjol dan mampu menghidupkan jalannya diskusi adalah kelompok 6 . Kelompok inilah yang telah mengindikasikan sehingga tim peneliti dapat menyimpulkan bahwa penerapan siklus 2 manambah baiknya proses pembelajaran. Dan secara umum, proses pembelajaran dengan strategi inkuiri terpimpin telah menunjukkan meningkatnya kualitas pembelajaran mata kuliah Sejarah Asia Timur pada Program Studi Pendidikan Sejarah Fakultas Keguruan dan IImu Pendidikan ini. Terhadap silabi mata kuliah, berdasarkan hasil angket yang disebarkan rata-rata mahasiswa merasa tertarik dan tertantang dengan silabi yang disodorkan oleh dosen. Hal demikian juga terjadi dalam pengembangan model dan penerapan strategi inkuiri dimana mahasiswa merasa senang terhadap pengembangan proses pembelajaran. Begitu pula dengan diterapkannya siklus kedua yang dianggap lebih menantang dan menjadikan semakin impresifnya proses pembelajaran.

\section{Pembahasan dan Analisis}

Sesuai dengan kompleksitas dan globalnya kecenderungan dan perkembangan masyarakat dalam perjalanan sejarahnya, maka sudah pada tempatnyalah apabila persepektif pengajaran sejarah berorientasi pada masa depan. Hal ini berarti akan memerlukan orientasi, atau mungkin lebih tepat perluasan wawasan pengajaran sejarah, yaitu dari orientasi pengajaran sejarah yang menekankan aspek masa kelampauannya (past oriented), perlu diperluas kearah orientasi pengajaran sejarah berwawasan masa depan (future oriented). Penekanan wawasan pengajaran sejarah pada masa depan ini, pada dasarnya juga sesuai dengan hakekat tujuan pendidikan yang mempersiapkan kehidupan masa depan bagi generasi penerus. Konsep masa lampau adalah guru terbaik bagi masa depan, dapat menjadi salah satu perspektif yang strategis dalam menempatkan konsep wawasan masa depan dalam pengajaran sejarah yang dinamis (Djoko Suryo: 2005: 3). Sejalan dengan teori Fenton (1967: 262), bahwa berdasarkan observasi terhadap strategi pembelajaran yang dilakukan oleh para pengajar sejarah, ternyata strategi itu bergerak pada suatu kontinum dari strategi ekspositori sampai pada strategi inkuiri. Strategi ekspositori menunjukkan keterlibatan pengajar secara penuh menuntut keterlibatan mental pengajar untuk mampu memilih model dan metode mengajar yang sesuai dengan beban dan isi materi serta tujuan yang akan dicapai. Penentuan terhadap satu model mengajar akan membuka kemungkinan untuk menggunakan beberapa metode mengajar. Sedangkan strategi inkuiri menunjukkan keterlibatan mahasiswa atau peserta didik secara penuh dalam kegiatan belajar mengajar. Strategi inkuiri yang 
diterapkan dalam mata kuliah Sejarah Asia Timur ini juga menunjukkan proses pembelajaran yang berpusat pada mahasiswa. Proses pembelajaran menuntut mahasiswa untuk aktif dan kreatif dalam mencari sumbersumber, menemukan masalah, dan memecahkannya berdasarkan kemampuan interpretasi masing-masing. Konsep inkuiri ini tidak sepenuhnya pembelajaran berbasis mahasiswa, melainkan adanya keterlibatan dosen dalam memimpin dan mengarahkan proses pembelajaran.

Oleh karena itu, tim peneliti menyepakati lahirnya konsep dan paradigma yang betul-betul baru yakni adanya strategi atau metode inkuiri terpimpin dalam proses pembelajaran mahasiswa atau peserta didik pada umumnya. Konsep inkuiri terpimpin ini lahir dari pemikiran bahwa meskipun proses pembelajaran sudah berubah paradigma dari pembelajaran konvensional yang berpusat pada pengajar yang beralih menjadi pembelajaran mutakhir yang berpusat mahasiswa sesuai dengan tuntutan kurikulum berbasis kompetensi, namun peranan dosen sebagai pengajar dan pendidik, tidak akan pernah dapat digantikan oleh konsep besar manapun. Sesuai pula dengan teori belajar yang umum, metode inkuiri merupakan suatu metode atau strategi pembelajaran yang memungkinkan para peserta didik untuk menemukan jawabannya sendiri (Soewarso, 2000: 57).

Metode inkuiri adalah metode pembelajaran yang dalam penyampaian bahan pelajarannya tidak dalam bentuknya yang final, atau dalam artian tidak langsung. Artinya, dalam penyampaian metode inkuiri peserta didik sendirilah yang diberi peluang untuk mencari (menyelidiki/meneliti) dan memecahkan sendiri jawaban (permasalahan) dengan mempergunakan teknik pemecahan masalah. Namun demikian pengajar bertindak sebagai pengarah, mediator, dan fasilitator, yang wajib memberikan informasi yang relevan, sesuai dengan permasalahan atau materi pelajaran. Hal tersebut dapat berlangsung dalam kelompok-kelompok kecil dalam kelas melalui diskusi dan bermain peran. Dalam kegiatan ini peserta didik dituntut aktif terlibat dalam situasi belajar. Peserta didik menyadari masalah, mengajukan pertanyaan, selanjutnya menghimpun informasi sebelum mengambil keputusan (Munandar, 1995: 85). Dengan demikian sangat jelas metode inkuiri memberikan kebebasan yang besar pada peserta didik untuk mengembangkan dirinya, meskipun tidak terlepas dari peranan dosen dalam memimpin, membimbing, dan memberi arahan dalam proses pembelajaran.

Begitu pula dengan penerapan metode inkuiri dalam pembelajaran mata kuliah Sejarah Asia Timur pada Program Studi Pendidikan Sejarah, menunjukkan keanekaragaman pencerminan dan kecenderungan yang mengacu pada teori-teori inkuiri yang berpola interpretatif. Inkuiri terpimpin sebagaimana konsep baru yang dikemukakan, dalam artian proses inkuiri tidak melepaskan strategi ekspositori yang mengkondisikan peranan dosen dalam proses pembelajaran. Dengan didahului oleh strategi ekspositori, maka mahasiswa mendapat arahan yang jelas tentang status mata kuliah yang ditempuhnya, dan mendapat masukkan yang bermakna tentang strategi untuk mempelajarinya. Namun demikian yang menjadi permasalahan pokok adalah tersedianya sumber belajar yang memadai sehingga proses pembelajaran dengan strategi apapun dapat berjalan dengan baik.

\section{Kesimpulan}

Berdasarkan hasil pembahasan dan analisis dalam penelitian ini, maka dapat disimpulkan bahwa dengan penerapan metode inkuiri yang diawali dengan strategi ekspositori dan diakhiri dengan strategi inkuiri dalam pembelajaran mata kuliah Sejarah Asia Timur di Program Studi Pendidikan Sejarah, kualitas pembelajaran mahasiswa meningkat. Kontinum ekspositori menunjukkan keterlibatan dosen dalam memberikan arahan yang jelas tentang apa-apa yang harus dikerjakan oleh mahasiswa. Kemudian strategi inkuiri dimana keterlibatan mahasiswa secara penuh dalam merumuskan masalah materi pembelajaran, menyusun hipotesa, memperjelas dan menguraikan hipotesa, menguji hipotesa, pembuktian, dan generalisasi. Pola pembelajaran bergerak dari 
strategi ekspositori yang melibatkan dosen dalam pengarahan awal, sampai pada strategi inkuiri yang melibatkan peranan mahasiswa secara penuh. Dengan strategi inkuiri ini, terjadi pembelajaran yang impresif dan dialogis yang melibatkan seluruh mahasiswa dalam proses pembelajaran. Ketika dipadu dengan metode diskusi, maka peranan mahasiswa dalam proses inkuiri semakin tampak dan memberi warna baru tentang perlunya pembelajaran yang multimetode dan multimedia.

\section{Implikasi dan Saran}

Sebagai saran bagi para staf pengajar khususnya pengajar sejarah, bahwa pembelajaran yang bermakna harus dinamis dan memerlukan kreativitas dari pengajar untuk mengembangkannya. Apabila pengajaran sejarah tetap terpola pada strategi konvensional, maka pengajaran sejarah yang demikian telah terperangkap pada bidang gelap yang menyesatkan. Pengajarah sejarah akan kehilangan arah dan makna, atau lebih buruk lagi dampak destruktruktifnya akan ditinggalkan oleh orang banyak. Dengan demikian, tugas pengajar adalah selalu tanggap terhadap perkembangan situasi, termasuk harus memiliki kompetensi dalam merespon arus perubahan yang semakin global dan kompetitif.

\section{DAFTAR PUSTAKA}

Banathy, Bela H. 1992. A Systems View of Education: Concepts and Principles for Effective Practice. Englewood Cliffs: Educational Technology Publications.

Beyer. Barry K. 1999. Inquiri in the Social Studies Classroom Strategy for Teaching. Ohio: Charles Merry Publishing Company.

Budiono dan Ella Yulelawati. 1999. Penyusunan Kurikulum Berbasis Kemampuan. Jurnal Pendidikan dan Kebudayaan, No.019, Tahun Ke-5 Oktober. Jakarta: Balitbang Depdiknas.
Eko, Budi Sucipto. 2001. Inquiry as a Method of Implementing Active Learning. Dalam Jurnal IImu Pendidikan, No.8. Vol.3., hlm.27.

Freire, Paulo. 1999. Politik Pendidikan: Kebudayaan, Kekuasaan, dan Pembebasan. Terj. Agung Prihantoro. Yogyakarta: Pustaka Pelajar.

Gunning, Dennis. 1978. The Teaching of History. London: Cronhelm. Hariyono. 1992. Pengajaran Sejarah dan Egenwelt Subjek-Didik. Historika. No.1 Vol 1. Surakarta: PPs Pendidikan Sejarah IKIP Jakarta KPK UNS.

Kartodirdjo, Sartono.1982. Pemikiran dan Perkembangan Historiografi Indonesia: Suatu Alternatif. Jakarta: PT Gramedia.

Maarif, Ahmad Syafii. 1995. Historiografi dan Pengajaran Sejarah. Yogyakarta: FPIPS IKIP Yogyakarta.

MD. Dahlan. 1999. Model-Model Mengajar. Bandung Diponegoro. Miles, M.B. and Huberman, A.M. 1984. Qualitative Data Analysis: A Sourcebook of New Methods. Beverly Hills CA: Sage Publications.

Patton, M.Q. 1980. Qualitative Evaluation Methods. Beverly Hills, CA.: Sage Publication. Saylor, J.G. 1981. Curriculum Planning for Better Teaching and Learning, Fourth Edition. Japan: Holt.

Soedjatmoko. 1976. Kesadaaran Sejarah dalam Pembangunan. Prisma No. 7. Jakarta.

Soewarso. 2000. Cara-cara Penyampaian Pendidikan sejarah Untuk Membangkitkan Minat Peserta Dikid Mempelajari sejarah Bangsanya. Jakarta: Dirjen dikti Depdiknas.

Spradley, J.P. 1980. Participant Observation. New York, N.Y.: holt, Rinehart, and Winston.

Surakhmad, Winarno. 2000. Metodologi Pengajaran Nasional. Jakarta: UHAMKA 
Suud, Abu. 1994. Format Metodologi

Pengajaran Sejarah Dalam

Transformasi Nilai dan Pengetahuan.

Makalah Seminar Nasional

Memantapkan Format Metodologi

Pendidikan Sejarah dan Sosialisasi

Kurikulum 1994. Yogyakarta: IKIP Yogyakarta.

Utami Munandar. 1995. Mengembangkan Kreativitas anak Berbakat. Jakarta: Gramedia.

Winataputera, US. 1992. Model-Model Pembelajaran. Jakarta: Depdikbud. Zamroni. 2000. Paradigma Pendidikan Masa Depan. Yogyakarta: PT Bayu Indra Grafika. 